\title{
Effectiveness of Ozone on Postharvest Conservation of Pear (Pyrus communis L.)
}

Ernandes R Alencar ${ }^{{ }^{*}}$, Lêda RA Faroni ${ }^{2}$, Michele S Pinto ${ }^{3}$, Andre R da Costa ${ }^{2}$ and Antônio F Carvalho ${ }^{3}$

${ }^{1}$ Faculdade de Agronomia e Medicina Veterinária, Universidade de Brasilia, Campus Darcy Ribeiro, Brasília, DF, CEP 70.970-000, Brazil

${ }^{2}$ Departamento de Engenharia Agrícola, Universidade Federal de Viçosa, Av. Peter Henry Rolfs, s/n, Campus, Viçosa, MG, CEP $36570-000$, Brazil

${ }^{3}$ Departamento de Tecnologia de Alimentos, Universidade Federal de Viçosa, Av. Peter Henry Rolfs, s/n, Campus, Viçosa, MG, CEP $36570-000$, Brazil

*Corresponding author: Ernandes Rodrigues de Alencar, Faculdade de Agronomia e Medicina Veterinária, Universidade de Brasília, Campus Darcy Ribeiro, Brasília, DF, CEP 70.970-000, Brazil, Tel: 618207 5633; E-mail: ernandesalencar@unb.br

Rec date: Mar 11, 2014; Acc date: Apr 17, 2014; Pub date: Apr 25, 2014

Copyright: (c) 2014 Ernandes RA, et al. This is an open-access article distributed under the terms of the Creative Commons Attribution License, which permits unrestricted use, distribution, and reproduction in any medium, provided the original author and source are credited.

\begin{abstract}
The objective of this study was to evaluate the effect of ozone $\left(\mathrm{O}_{3}\right)$ treatment on postharvest quality of pear cv. 'Williams'. Pears were exposed to gaseous ozone at the concentration of $100 \mathrm{ppm}$ for 60 minutes in a flow rate of $2.3 \mathrm{~L} \mathrm{~min}^{-1}$ and stored in BOD incubators at $25 \pm 2^{\circ} \mathrm{C}, 75-85 \%$ relative humidity, for 13 days. Fruit quality was evaluated at the beginning and at days 3, 6, 9 and 13 of storage for the following variables: Fresh Mass Loss (FML), Titratable Acidity (TA), Total Soluble Solids (TSS), $\mathrm{pH}$ and microbiological examination (total aerobic mesophilic count and total yeast and mold count). The variables Fresh Mass Loss (FML) and Total Soluble Solids (TSS) were significantly affected by the ozone treatment. In general, the microorganism counts in ozonatedpears were lower than those in untreated pears. The treatment with gaseous ozone increased the shelf life of the pears with efficient microorganism control, did not affect the quality parameters $\mathrm{pH}$ and titratable acidity and delayed soluble solids increase.
\end{abstract}

Keywords: Ozonation; Ripening; Storage

\section{Introduction}

Pears are grown in many countries throughout the world, which makes it a produce of great importance and acceptance in international markets [1]. In 2012, the major producing countries were China, accounting for about $68.3 \%$ of world production, United States (3.3\%), Argentina (3.0\%), Italy (2.7\%) and Turkey (1.9\%) [2].

In Brazil, the production of quality pears on a commercial scale is small and commercial orchards are located in the Southern states. During the 2001 to 2005 period, the average domestic production was 18,800 tons [3]. The state of Rio Grande do Sul is the largest producer, accounting for $47 \%$ of the domestic production in 2006 . The growing of low quality cultivars has favored imports of fresh pear mainly from Chile and Argentina. To increase per capita consumption by $0.5 \mathrm{~kg}$ $\mathrm{yr}^{-1}$, the country must produce fruit of similar quality to the imported pear [4].

Good postharvest conservation of pear requires cold environment and adequate air relative humidity. Generally, pears can be stored up to three months at temperatures between $1.5^{\circ} \mathrm{C}$ and $0^{\circ} \mathrm{C}$ and relative humidity between $90 \%$ and $95 \%$. Good ventilation is also required, because pearpeel is sensitive to sulfur dioxide $\left(\mathrm{SO}_{2}\right)$ and carbon dioxide $\left(\mathrm{CO}_{2}\right)$ that are used to preserve fruit in good condition for fresh consumption [5,6]. According to these authors, a number of storage unitsare provided with mechanisms to control the concentration of these gases, which varies with the variety. These mechanisms, however, increases storage costs. Therefore, new alternatives are needed that allow good product conservation, but without increasing production costs. In this sense, ozonation stands out among the new techniques proposed for food preservation $[7,8]$.
Ozone $\left(\mathrm{O}_{3}\right)$ is a potent antimicrobial agent due to its strong oxidizing potential and has wide application in the food industry. Ozone is one of the most powerful known sanitizers. The high reactivity, penetrability and spontaneous decomposition to a nontoxic product $\left(\mathrm{O}_{2}\right)$ make ozone an alternative that enables food safety from a microbiological point of view, mainly because ozone has been classified as a GRAS (Generally Recognized as Safe) material in the United States and approved by the FDA (Food and Drug Administration) for direct contact with foods. Usually, low ozone concentrations and short contact times are needed to inactivate bacteria, fungi, yeasts, parasites and viruses, but the susceptibility of microorganisms to ozone varies, among other factors, with the physiological state of the culture, $\mathrm{pH}$, temperature, humidity and the presence of additives [9-17].

Ozone is most commonly used in food surface decontamination and water treatment. The gas is also very useful in controlling insect pests of stored grain, detoxification and elimination of mycotoxins and pesticide residues in agricultural products [18-21]. Ozone is therefore considered an alternative capable of meeting the needs of the food industry due to its potential to increase produce shelf life, reduce production losses and, consequently, create conditions for market expansion. Another advantage is the rapid on-site generation of ozone and the possibility of being applied to fruit, for example, as a gas, (dry method) or as ozonated water (wet method) [22]. These two application methods are interesting from a commercial point of view, because they produce no toxic waste, which enables producers and processors to adapt to new regulations of phytosanitary control. Another key aspect is that the technology benefits consumers by making available on the market pesticide and additive-free products and, especially, safe and high sensory quality foods. 
In view of the foregoing, the objective of this study was to evaluate the shelf life and quality of pear (Pyrus communis) cv. 'Williams' treated with ozone gas.

\section{Materials and Methods}

Pears (Pyrus communis) cv. 'Williams' were used in this study and had yellowish-green colour without brown patches, weird odors and without defects from mechanical movement. Initially the fruits were placed into a $6.0 \mathrm{~L}$ plastic container. Thereafter, $4.0 \mathrm{~kg}$ of pears were fumigated with an ozone concentration of $100 \mathrm{ppm}$ and flow rate of $4.6 \mathrm{~L} \mathrm{~min}^{-1}$ for $60 \mathrm{~min}$. Ozone was generated by Dielectric Barrier Discharge (DBD) using moisture-free oxygen. In the control treatment, the fruits were fumigated with only oxygen.

The residual ozone concentration after passaging through the container with $4.0 \mathrm{~kg}$ of pears was determined by the iodometric method [23] which consists in bubbling ozone into $50 \mathrm{~mL}$ solution of potassium iodide $(\mathrm{KI}) 1 \mathrm{~N}$, and Iodine $\left(\mathrm{I}_{2}\right)$ being produced. To ensure that the reaction shifts towards producing $\mathrm{I}_{2}$, the medium had to be acidified with $2.5 \mathrm{~mL}$ sulphuric acid $\left(\mathrm{H}_{2} \mathrm{SO}_{4}\right) 1 \mathrm{~N}$. The solution was then titrated with sodium thiosulphate $\left(\mathrm{Na}_{2} \mathrm{~S}_{2} \mathrm{O}_{3}\right) 0.005 \mathrm{~N}$, and a $1 \%$ starch solution was used as an indicator.

Pears were then packaged in expanded polystyrene (EPS), two fruit per tray. Each tray was covered with self-adhesive polyvinyl chloride (flexible PVC) $10 \mathrm{~mm}$ thick and stored in BOD incubators at $25 \pm 2^{\circ} \mathrm{C}$ and $75-85 \%$ relative humidity for 13 days.

Pear quality was evaluated in the beginning of the storage period and at days 3, 6, 9 and 13 based on the following variables: Fresh Mass Loss (FML), titratable acidity (TA), Total Soluble Solids (TSS), pH, microbiological examination (total aerobic mesophilic count and total yeast and mold count) and visual analysis.

FML was determined by subtracting the final fresh mass from the initial fresh mass after each storage period and expressed as a percentage. TA was determined by titration performed [24] and results expressed as $\%$ in fresh pulp, considering malic acid as predominant. The $\mathrm{pH}$ was measured with a digital $\mathrm{pH}$ meter and the total soluble solids content was measured by a refractometer and expressed in ${ }^{\circ}$ Brix.

Microbiological analyses were performed by surface spread plating with each sample diluted in peptone water $(0.1 \%)$. Total mesophilic aerobic bacteria were counted on standard Plate Count Agar (PCA) incubated at $35^{\circ} \mathrm{C}$ for 48 hours and expressed in colony forming units per gram $\left(\mathrm{CFU} \mathrm{g} \mathrm{g}^{-1}\right)$. The count of filamentous fungi and yeast was performed on Potato Dextrose Agar medium (PDA) acidified with $10 \%$ tartaric acid. The plates were incubated at $25^{\circ} \mathrm{C}$ for $3-5$ days and the results expressed in CFU/g.

The experiment was arranged in a completely randomized design and each sample consisted of four pears. The results were analyzed using the analysis of variance at $5 \%$ probability in SAEG 9.1. Descriptive statistics were used to present the qualitative parameters of ozonated or non-ozonated pear during the period of storage and graphs were plotted in Sigma Plot 2001.

\section{Results and Discussion}

Figure 1 shows the residual ozone concentration as a function of time of exposure of pears to gas. The residual ozone concentration after passing through the container with the fruits ranged from 0 to 33 ppm in 60 minutes of application. Ozone is a highly reactive molecule with a half-life that ranges between 15 and $50 \mathrm{~min}$, breaking down to $\mathrm{O}_{2}$, and shows no residual activity in disease control. Ozone half-life is reduced in the presence of reactive materials, commodities, storage unitsand others [25].

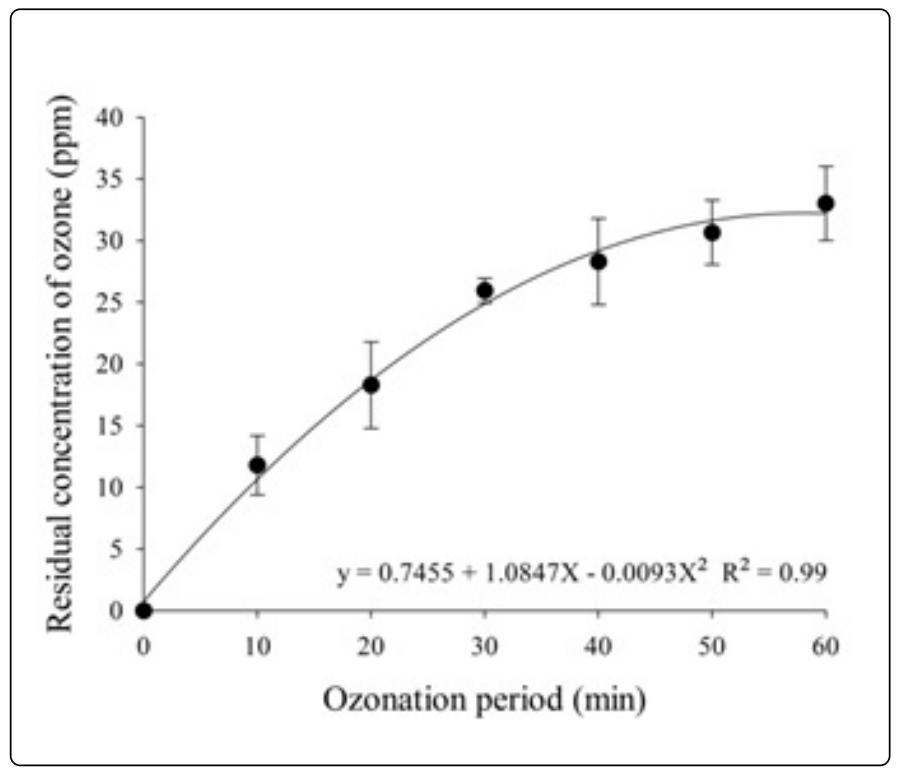

Figure 1: Residual concentration of ozone in function of the ozonation period of pears.

The analysis of variance showed significant difference $(\mathrm{p}<0.05)$ in Fresh Mass Loss (FML) of pears from the interaction of treatment or no treatment with ozone and storage time. Figure 2 shows the regression of Fresh Mass Loss (FML) of fruits stored for 13 days. The adjusted regression equations and their correlation coefficients relating mass loss and storage time are shown in Table 1.

\begin{tabular}{|l|l|l|}
\hline Treatment & Adjusted equations & $R^{2}$ \\
\hline Non-ozonated pear & $y=-0.0139+0.6381 X-0.0140 X 2$ & 0.98 \\
\hline Ozonated pear & $y=-0.0772+1.0397 X-0.0321 X 2$ & 0.99 \\
\hline
\end{tabular}

Table 1: Adjusted regression equations for fresh mass loss in pears untreated and treated with $100 \mathrm{ppm}$ of ozone for $60 \mathrm{~min}$ and stored at $25^{\circ} \mathrm{C}$ for 13 days. ( $\mathrm{y}$ - Fresh mass loss; $\mathrm{X}$ - period ozonization)

FML increased during storage regardless of the ozone treatment (Figure 3). On the other hand, FML in ozonized pears was higher than in non-ozonated pears, which can be explained by the high oxidation power of ozone. Salvador et al. [26] also observed similar behavior in persimmon. These authors treated the fruits with ozone $(0.15 \mathrm{ppm})$ for 15 days and also found increased release of electrolytes in ozonated persimmons. This behavior indicates the reaction of the gas with the cuticle, whose main function is to control water loss by transpiration, and with lipoprotein components [27]. In contrast, other studies reported a lower water loss in ozonized fruits, for instance, strawberry treated with $1.5 \mathrm{ppm}$ ozone at $2^{\circ} \mathrm{C}$ for 3 days [28]. The largest FML in the ozonized fruit is a negative effect of the treatment. The water content is directly related to sensory quality of the product, occurring change in texture. 


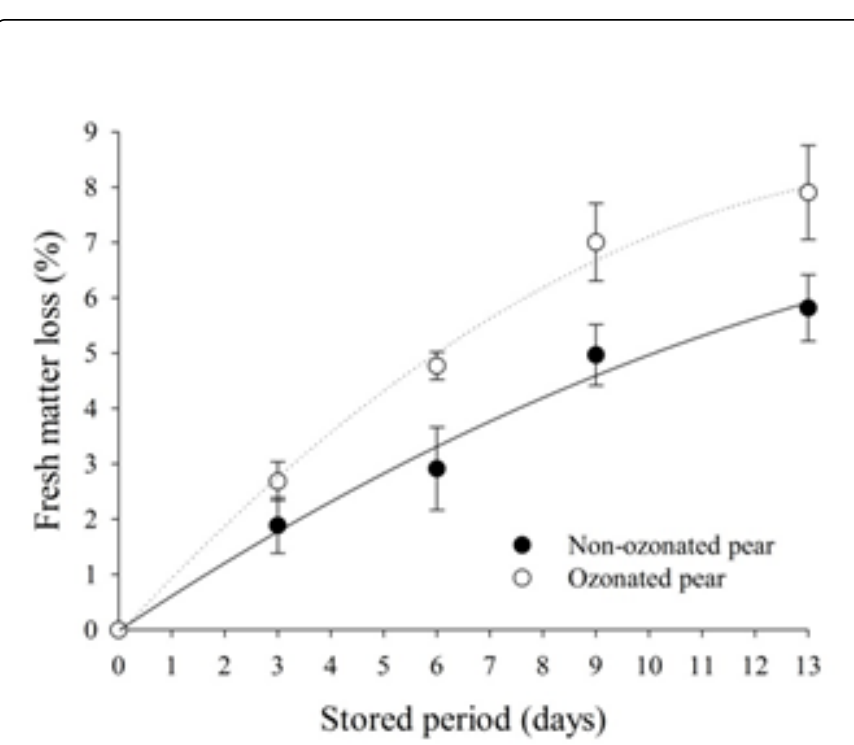

Figure 2: Fresh mass loss (\%) in pears untreated and treated with $100 \mathrm{ppm}$ of ozone for $60 \mathrm{~min}$ and stored at $25^{\circ} \mathrm{C}$ for 13 days.

The analysis of variance showed no significant difference $(\mathrm{p}>0.05)$ for titratable acidity (TA) and $\mathrm{pH}$ from the interaction of treatment or no treatment with ozone and the storage period. The means for TA and $\mathrm{pH}$ of fruits untreated and treated with ozone for 13 days are presented in Figures 3 and 4. Similarly, Holtz [29] found no significant differences for $\mathrm{pH}$ in strawberry untreated and treated with $50 \mathrm{ppm}$ ozone for 30 and 60 minutes over 15 days of storage.

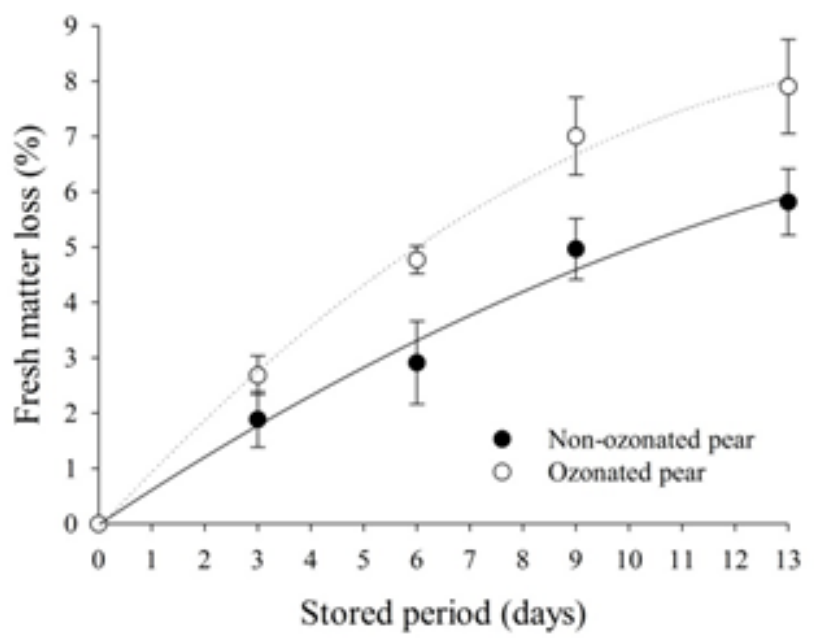

Figure 2: Fresh mass loss (\%) in pears untreated and treated with $100 \mathrm{ppm}$ of ozone for $60 \mathrm{~min}$ and stored at $25^{\circ} \mathrm{C}$ for 13 days.

The analysis of variance showed no significant difference $(\mathrm{p}>0.05)$ for titratable acidity (TA) and $\mathrm{pH}$ from the interaction of treatment or no treatment with ozone and the storage period. The means for TA and $\mathrm{pH}$ of fruits untreated and treated with ozone for 13 days are presented in Figures 3 and 4. Similarly, Holtz [29] found no significant differences for $\mathrm{pH}$ in strawberry untreated and treated with $50 \mathrm{ppm}$ ozone for 30 and 60 minutes over 15 days of storage.

The analysis of variance showed significant difference $(p<0.05)$ for Total Soluble Solids (TSS) from the interaction of treatment or no treatment with ozone and the storage period. Mean TSS values are shown in Figure 5. Non-ozonated pears reached the highest TSS concentration after six days of storage, corresponding to $10.2{ }^{\circ} \mathrm{Brix}$, and decreased later. Climacteric fruits, such as pears, undergo considerable changes in sugar contents, which increase after harvest and during storage for a short time, but after a longer time, the contents of all sugars decrease [30]. On the other hand, the ozonized pears had the highest TSS level, $10.0^{\circ}$ Brix, after 13 days. This difference indicates a delay of pear senescence as a result of the ozone treatment and, consequently, increased shelf life.

In general, aerobic mesophilic count and total yeast and mold count inozonated pears were lower than in untreated pears over the storage period, confirming the ozone microbicidal capacity as one of the most potent known sanitizers [9]. There was rapid growth of aerobic mesophiliconly in non-zonatedpears (Table 2). Growth of filamentous fungi and yeasts occurred only from day 9 of storage in non-ozonated pears, which was coincidentally accompanied by a decrease in the aerobic mesophilic count and probably a result from the decrease in $\mathrm{pH}$ (Figure 4). The $\mathrm{pH}$ of non-ozonated pears at the beginning of the storage period was 5.4 and after 13 days decreased to 4.3 . This trend is observed in microbial counts because, in favorable conditions, bacteria grow more rapidly than fungi. Besides, microorganisms generally grow between $\mathrm{pH} 6.6$ and 7.5, but fungi and yeasts are less demanding and $\mathrm{pH}$ below 4.0 favors their growth [31]. The inactivation/inhibition of micro-organism development by ozone through the oxidation of vital cell components is a complex process in which the gas acts on parts of the membrane and the cell wall, such as unsaturated fatty acids, glycoproteins and glycolipids, as well as elements of the cell content $[22,32,33]$.

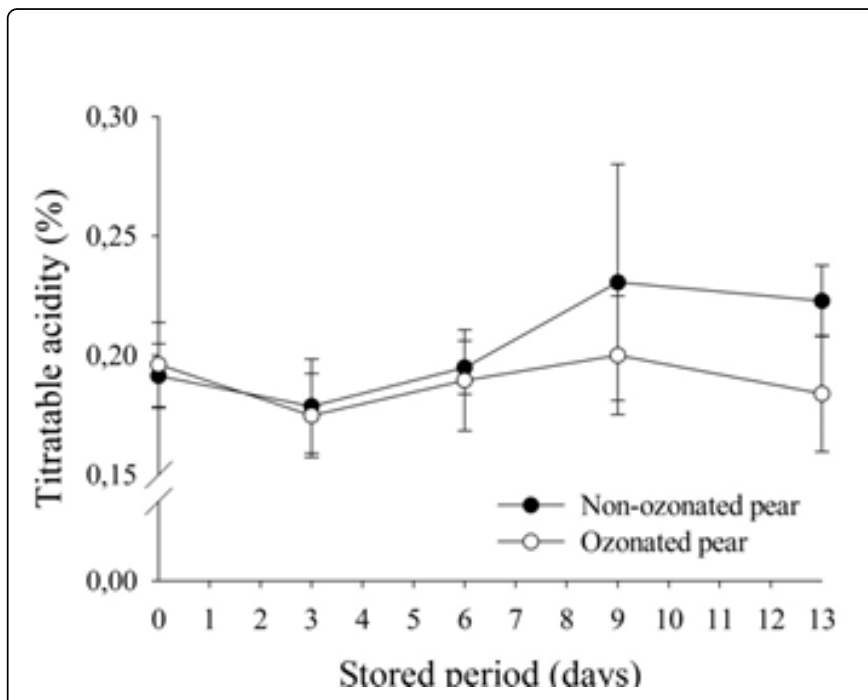

Figure 3: Means for titratable acidity (TA) of pears untreated and treated with $100 \mathrm{ppm}$ ozone for 60 minutes and stored at $25^{\circ} \mathrm{C}$ for 13 days. 
Citation: Alencar ER, Faroni LR, Pinto MS, da Costa AR, Carvalho AF (2014) Effectiveness of Ozone on Postharvest Conservation of Pear (Pyrus communis L.). J Food Process Technol 5: 317. doi:10.4172/2157-7110.1000317

Page 4 of 5

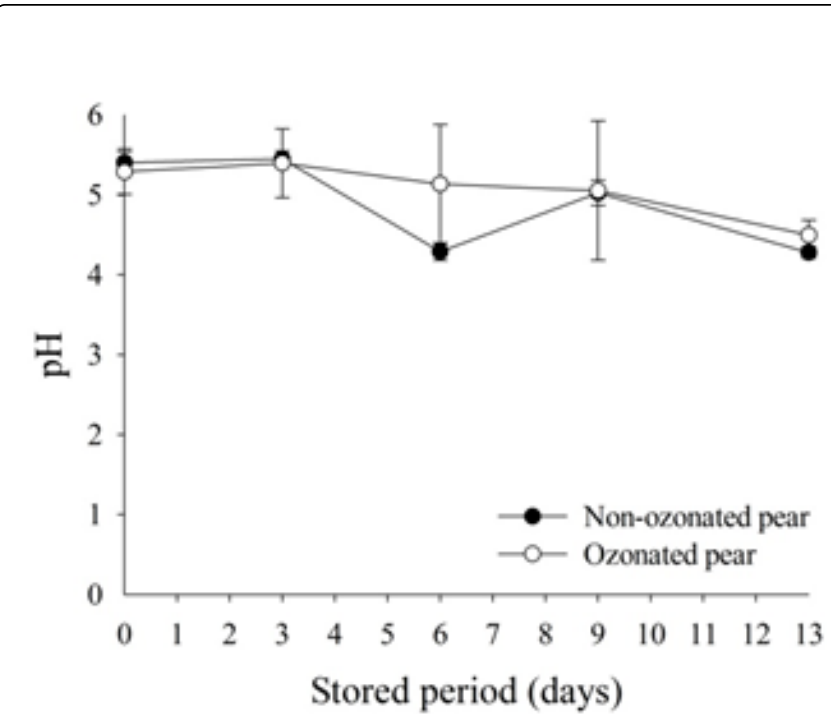

Figure 4: Mean $\mathrm{pH}$ values of pears untreated and treated with 100 ppm ozone for 60 minutes and stored at $25^{\circ} \mathrm{C}$ for 13 days.

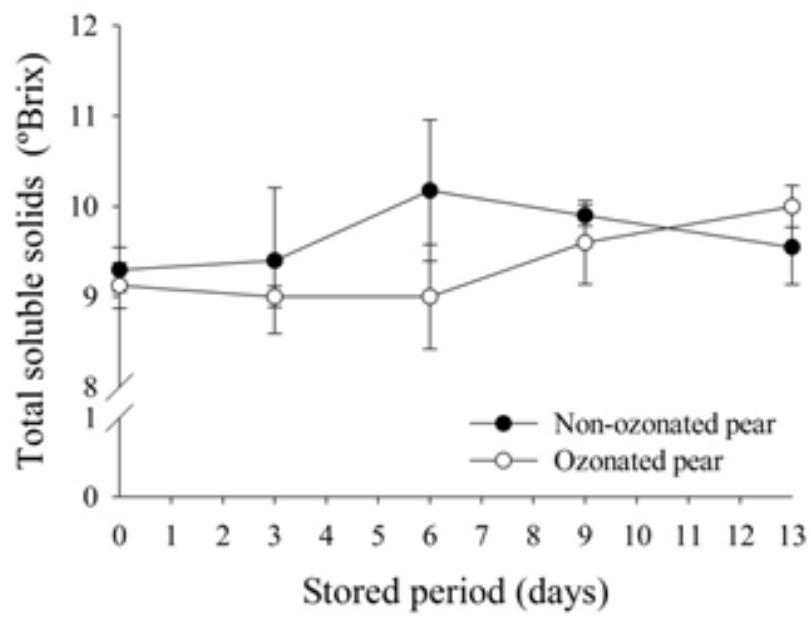

Figure 5: Means of total soluble solids (TSS) of pear treated or untreated with $100 \mathrm{ppm}$ of ozone for $60 \mathrm{~min}$ and stored at $25^{\circ} \mathrm{C}$ for 13 days.

The efficiency of the ozonation treatment was also confirmed by visual analysis. Circular brown spots appeared on pears untreated with ozone after six days of storage. Figure 6 shows the external appearance of the pears treated and untreated with ozone gas after 13 days of storage. These lesions are characteristic of anthracnose [34], which in this case is caused by Colletotrichum gloeosporioides (Penz) and $C$. acutatum Simmonds JH [35]. The lesions caused by these microorganisms also affected the flesh of the non-ozonated fruit, but not the fruit treated with ozone (Figure 7). Colletotrichum spp. can remain quiescent in non-harvested unripe fruit over many weeks [36-37]. However, symptoms appear after harvest, during transport and marketing, as these fruits become more susceptible to disease during ripening and senescence [38].

\begin{tabular}{|l|l|l|l|l|}
\hline \multirow{2}{*}{$\begin{array}{l}\text { Time } \\
\text { (days) }\end{array}$} & \multicolumn{2}{|l|}{\begin{tabular}{l} 
Aerobic mesophilic \\
\cline { 2 - 5 } \\
poar
\end{tabular}} & Mould and yeasts \\
\cline { 2 - 5 } & log $\mathrm{CFU} \mathrm{g}^{-1}$ & $\begin{array}{l}\text { Ozonated } \\
\text { pear }\end{array}$ & $\begin{array}{l}\text { Non-ozonated } \\
\text { pear }\end{array}$ & $\begin{array}{l}\text { Ozonated } \\
\text { pear }\end{array}$ \\
\hline 0 & $2.0 \pm 0.3$ & $<1^{*}$ & $\operatorname{log~CFU~g}^{-1}$ & log $\mathrm{CFU} \mathrm{g}^{-1}$ \\
\hline 3 & $3.1 \pm 0.1$ & $<1^{*}$ & $<1^{*}$ & $<1^{*}$ \\
\hline 6 & $3.2 \pm 0.5$ & $<1^{*}$ & $<1^{*}$ & $<1^{*}$ \\
\hline 9 & $3.7 \pm 0.4$ & $<1^{*}$ & $2.6 \pm 0.3$ & $<1^{*}$ \\
\hline 13 & $<1^{*}$ & $<1^{*}$ & $3.0 \pm 0.2$ & $<1^{*}$ \\
\hline
\end{tabular}

Table 2: Total count of aerobic mesophilic, mould and yeasts on pears untreated and treated with $100 \mathrm{ppm}$ of ozone for $60 \mathrm{~min}$ and stored at $25^{\circ} \mathrm{C}$ for 13 days. (Estimated Value ${ }^{\star}$ )

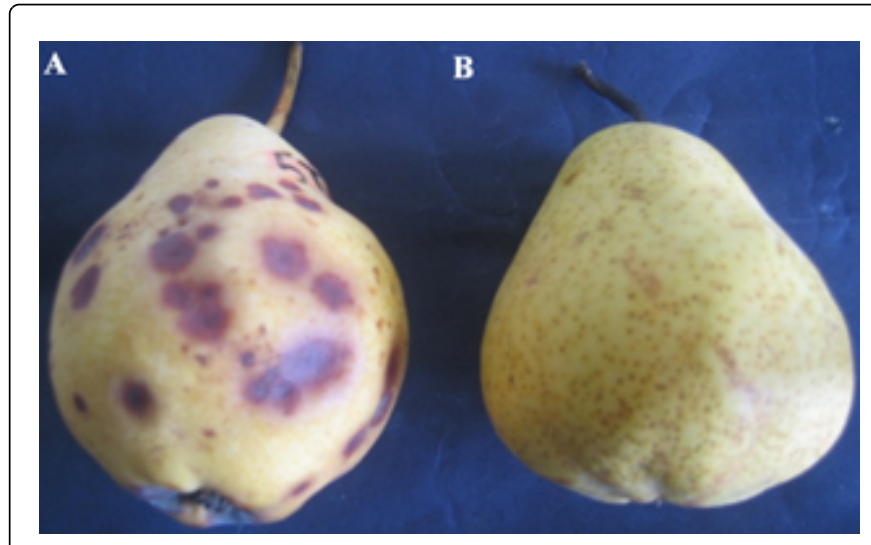

Figure 6: External appearance of pears untreated (A) and treated (B) with $100 \mathrm{ppm}$ of ozone for $60 \mathrm{~min}$ and stored at $25^{\circ} \mathrm{C}$ for 13 days.

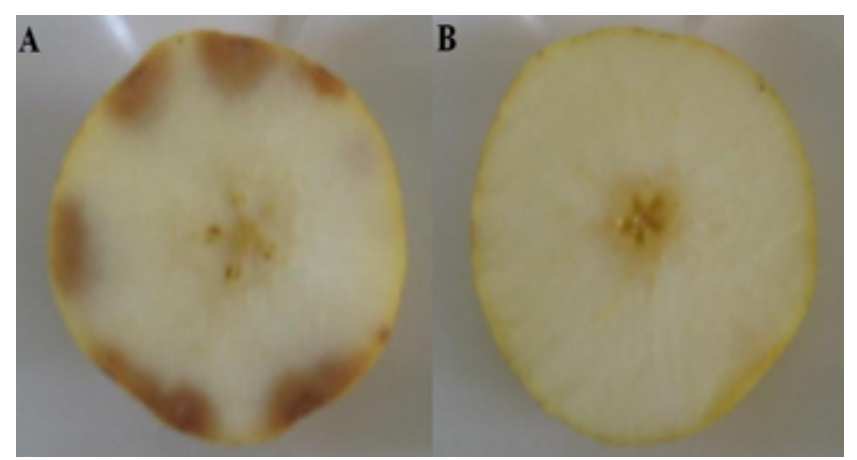

Figure 7: Cross section of pears untreated (A) and treated (B) with $100 \mathrm{ppm}$ of ozone for $60 \mathrm{~min}$ and stored at $25^{\circ} \mathrm{C}$ for 13 days.

\section{Conclusions}

The results of this study showed that the ozone treatment increases pear shelf life with efficient control of microorganisms and does not 
affect qualitative parameters such as $\mathrm{pH}$ and total acidity. It also slows the increase in total soluble solids, which is indicative of fruit ripening. However, it is recommended that further studies be undertaken with different combinations of ozone concentrations and exposure times, as well as feasibility study on the use of edible films to reduce the fresh mass loss of ozonized pears.

\section{References}

1. Fioravanço JC (2007) A cultura da pereira no Brasil: situação econômica e entraves para o seu crescimento. Infor Econ 37: 52-60.

2. FAO (2014) Food and Agriculture Organization of the United Nations. Food and Agricultural commodities production.

3. Instituto Brasileiro de Geografia e Estatística (2013) Produção agrícola municipal (anos 2002 a 2006)-quantidade produzida, valor da produção, área plantada e área colhida da lavoura permanente.

4. Coutinho EF, Malgarim MB, Souza EL, Treptow RO (2003) Postharvest quality of pear (Pyrus communis L.) cv. Carrick submitted to diferents storage conditions. Rev Bras Frutic 25: 417-420.

5. Sato GS, Assumpção R (2003) Cultivo da pêra no Brasil no estado de São Paulo. Infor Econ 33: 63-69.

6. Penteado SR, Franco JAM (2008) Pêra. In: Manual técnico das culturas CATI. Campinas: CIAGRO/CAT.

7. Wysok B, Jan U, Gomóka PM (2006) Ozone as an alternative disinfectant-a review. Pol J Food Nutr Sci 15/56: 3-8.

8. Tiwari BK, Donnell CPO, Cullen PJ (2009) New challenges in food science and technology: an industrial perspective. Trends Food Sci Tech 20: 180-181.

9. Khadre MA, Yousef AE, Kim JG (2001) Microbiological aspects of ozone applications in food: A review. J Food Sci 66: 1242-1252.

10. Puia C, Oroian I, Florian V (2004) Effect of ozone exposure on phytopathogenic microorganisms on stored apples. J Agr Sci 15: 9-13.

11. Suslow TV (2004) Ozone applications for postharvest disinfection of edible horticultural crops. University of California-Division of Agriculture and Natural Resources, Oakland, University of California, USA.

12. Stucki S, Schulze D, Schuster D, Stark C (2005) Ozonization of purified water systems. Pharm Eng 25: 1-7.

13. Pascual A, Llorca L, Canut A (2007) Use of ozone in food industries for reducing the environmental impact of cleaning and disinfection activities. Trends Food Sci Tech 18: S29-S35.

14. Yuk HG, Yoo MY, Yoon JW, Marshall DL, Oh DH (2007) Effect of combined ozone and organic acid treatment for control of Escherichia coli O157:H7 and Listeria monocytogenes on enoki mushroom. Food Control 18: 548-553.

15. Akbas MY, Ozdemir M (2008) Application of gaseous ozone to control populations of Escherichia coli, Bacillus cereus and Bacillus cereus spores in dried figs. Food Microbiol 25: 386-391.

16. Selma MV, Ibáñez AM, Allende A, Cantwell M, Suslow T (2008) Effect of gaseous ozone and hot water on microbial and sensory quality of cantaloupe and potential transference of Escherichia coli O157:H7 during cutting. Food Microbiol 25: 162-168.

17. Alencar ER, Faroni LRD, Pinto MS, Costa AR, Silva, TA (2013) Postharvest quality of ozonized nanicão cv. Bananas Rev Cienc Agron 44: 107-114.

18. Kim JB, Yousef AE, Dave S (1999) Application of ozone for enhancing the microbiological safety and quality of foods: A review J Food Protect 62: 1071-1087.
19. Rozado AF, Faroni LRD, Urruchi WMI, Guedes RNC, Paes JL (2008) Ozone application against Sitophilus zeamais and Tribolium castaneum on stored maize. Rev Bras Eng Agr Ambient 12: 282-285.

20. Sousa AH, Faroni LRD, Guedes RNC, Tótola MR, Urruchi WMI (2008) Ozone as a management alternative against phosphine-resistant insect pests of stored products. J Stored Prod Res 44: 379-385.

21. Alencar ER, Faroni LRD, Soares NFF, Silva WA, Carvalho MCS (2012) Efficacy of ozone as a fungicidal and detoxifying agent of aflatoxins in peanuts. J Sci Food Agr 92: 899-905.

22. Cullen PJ, Jiwari BK, O’Donnell CP, Muthukumarappan K (2009) Modelling approaches to ozone processing of liquid foods. Trends Food Sci Tech 20: 125-136.

23. Clescerl LS, Greenberg AE, Eaton AD (2000) Standard methods for the examination of water and wastewater. American Water Works Association.

24. Instituto Adolfo Lutz (2005) Métodos físico-químicos para análise de alimentos. Ministério da Saúde, Brasília, Distrito Federal, Brasil.

25. Spencer RJS (2003) Ozone as a post-harvest treatment for potatoes. M.Sc. University of Saskatchewan, Saskatoon, SK, Canada.

26. Salvador A, Abad A, Arnal L, Jávega JM (2006) Effect of ozone on postharvest quality of persimmon. J Food Sci 71: 443-446.

27. Rao MV, Koch JR, Davis KR (2000) Ozone: a tool for probing programmed cell death in plants. Plant Mol Bio 44: 345-358.

28. Nadas A, Olmo M, Garcia JM (2003) Growth of botrytis cinerea and strawberry quality in ozone-enriched atmospheres. J Food Sci 68: 1798-1803.

29. Holtz SG (2006) Aplicação de ozônio e de revestimentos comestíveis em morangos (Fragaria ananassa Duch.) minimamente processados. M.Sc. Universidade Federal de Viçosa, Viçosa.

30. Chitarra MI, Chitarra AB (2005) Pós-colheita de frutos e hortaliças; fisiologia e manuseio. Lavras: Editora UFLA.

31. Moraes CA, Gomes AP (2004) Segurança na produção de manga. Manga - Produção Integrada, Industrialização e Comercialização. Viçosa, Editora UFV.

32. Greene AK, Few BK, Serafini JC (1993) A comparison of ozonation and chlorination for the disinfection of stainless steel surfaces. J Dairy Sci 76: 3617-3620.

33. Guzel-Seydim ZB, Greene AK, Seydim AC (2004) Use of ozone in the food industry. Lebensm Wiss Technol 37: 453-460.

34. Silva KS, Rebouças TNH, Lemos OL, Bomfim MP, Bomfim AA (2006) Pathogenicity caused by Colletotrichum gloeosporioides (Penz) in different fruitful species. Rev Bras Frutic 28: 131-133.

35. Živković S, Stojanović S, Ivanović Ž, Gavrilović V, Popović T (2010) Screening of antagonistic activity of microorganisms against Colletotrichum acutatum and Colletotrichum gloeosporioides. Arch Biol Sci 62: 611-623.

36. Kuo KC (1999) Germination and appressorium formation in Colletotrichum gloeosporioides. P Natl Sci Council 23: 126-132.

37. Gomes LIS, Alves E, Santana EN, Castro HÁ (2012) Metodology of inoculation of Colletotrichum gloeosporioides on papaya fruits. Agrotrópica 24: 183-188.

38. Fernandes MCA, Santos AS, Ribeiro RLD (2001) In vitro sensitivity to benomyl of Colletotrichum gloeosporioides isolates from sweet pepper, garden egg and eggplant fruits. Arq Inst Biol 68: 89-95. 